\title{
MILITARY COLLABORATION AND NAZI PRINTED PROPAGANDA ON THE TERRITORY OF CRIMEA IN 1941-1944 (BASED ON THE MATERIALS OF NEWSPAPER GOLOS KRYMA)
}

\author{
Oleg V. Romanko \\ Crimean Federal University named after V.I. Vernadsky, Simferopol, Russian Federation
}

\begin{abstract}
Introduction. This paper deals with the problem of military collaboration as a factor of Nazi printed propaganda in the occupied Crimea. It is emphasized that, despite its relevance, this problem has not yet become the object of scientific research. Methods and materials. The publication is based on a wide range of published and unpublished sources from Russian and foreign archives. The analysis of the coverage of the collaborationist theme is based on the materials of the Russian-language occupation newspaper Golos Kryma ('Voice of Crimea'), which was published in Simferopol from 1941 to 1944 and was the basic printing body for the Nazi propaganda model implemented in Crimea. Analysis. With the help of general scientific and specific historical methods of research, as well as a systematic approach, the main theme of publications about the topic of military collaborationism, which were placed in the newspaper, is revealed. It is shown that until the spring of 1943 coverage of this problem was not systematic, for both Nazi propagandists and their local assistants. After the appearance of publications about the topics of the Vlasov movement and Russian liberation army, the coverage of the problem of military collaboration is changing radically. The reasons, which led to these changes, are specified. Results. It is argued that up to a certain point the forms and methods of presenting collaboration themes on the pages of the newspaper had an effective result. However, since the autumn of 1943, for a number of reasons, the force of their impact on the population fell sharply and has not restored.

Key words: World War II, Crimea, occupation, collaborationism, Golos Kryma ('Voice of Crimea'), Russian liberation army, A. A. Vlasov, V. I. Maltsev.

Citation. Romanko O.V. Military Collaboration and Nazi Printed Propaganda on the Territory of Crimea in 19411944 (Based on the Materials of Newspaper Golos Kryma). Vestnik Volgogradskogo gosudarstvennogo universiteta. Seriya 4, Istoriya. Regionovedenie. Mezhdunarodnye otnosheniya [Science Journal of Volgograd State University. History. Area Studies. International Relations], 2019, vol. 24, no. 1, pp. 130-139. (in Russian). DOI: https://doi.org/ 10.15688/jvolsu4.2019.1.11
\end{abstract}

\section{ВОЕННЫЙ КОЛЛАБОРАЦИОНИЗМ И НАЦИСТСКАЯ ПЕЧАТНАЯ ПРОПАГАНДА НА ТЕРРИТОРИИ КРЫМА В 1941-1944 гГ. (ПО МАТЕРИАЛАМ ГАЗЕТЫ «ГОЛОС КРЫМА»)}

\section{Олег Валентинович Романько}

Крымский федеральный университет им. В.И. Вернадского, г. Симферополь, Российская Федерация

Аннотация. В данной публикации рассматривается проблема военного коллаборационизма как фактора нацистской печатной пропаганды на территории оккупированного Крыма. Подчеркивается, что, несмотря на актуальность этой проблемы, она еще не становилась объектом научного исследования. Анализ освещения коллаборационистской тематики проведен на основе широкого круга опубликованных и неопублико- 
ванных источников из отечественных и зарубежных архивов, в частности, материалов русскоязычной оккупационной газеты «Голос Крыма», которая выходила в Симферополе с 1941 по 1944 г. и была базовым печатным органом для нацистской пропагандистской модели, реализованной в Крыму. При помощи общенаучных и конкретно-исторических методов познания, а также системного подхода выявлена основная тематика публикаций по теме военного коллаборационизма, которые размещались в газете. Определено, что до весны 1943 г. освещение этой проблемы не носило системного характера как для нацистских пропагандистов, так и для их местных помощников. После появления публикаций на тему Власовского движения и Русской освободительной армии направление анализа военного коллаборационизма меняется коренным образом. Указаны причины, которые привели к этим переменам. Утверждается, что до определенного момента формы и методы подачи коллаборационистской тематики на страницах «Голоса Крыма» имели эффективный результат. Однако с осени 1943 г. по ряду причин сила их воздействия на население резко упала и уже не восстановилась.

Ключевые слова: Вторая мировая война, Крым, оккупация, коллаборационизм, «Голос Крыма», Русская освободительная армия, А.А. Власов, В.И. Мальцев.

Цитирование. Романько О. В. Военный коллаборационизм и нацистская печатная пропаганда на территории Крыма в 1941-1944 гг. (по материалам газеты «Голос Крыма») // Вестник Волгоградского государственного университета. Серия 4, История. Регионоведение. Международные отношения. - 2019. - Т. 24, № 1. - C. 130-139. -DOI: https://doi.org/10.15688/jvolsu4.2019.1.11

Введение. Для привлечения населения оккупированных советских территорий в коллаборационистские формирования нацисты использовали различные способы: от материального поощрения до идеологической мотивации. При этом существенную роль в психологической обработке потенциальных добровольцев играла пропаганда, главным образом печатная. В многочисленных газетах и журналах, которые распространялись на оккупированных территориях, размещались публикации о тех, кто с оружием в руках противостоял СССР. В данном случае не являлся исключением и Крымский полуостров, где коллаборационистские проявления имели весьма серьезный характер как в количественном, так и в качественном измерениях.

Методы и материалы. Необходимо отметить, что печатные издания, выходившие в оккупированном Крыму, уже неоднократно анализировались, прежде всего, российскими авторами. Так, В.Н. Гурковичу принадлежит статья, посвященная тому, как в коллаборационистской прессе формировался образ противников нацистской Германии - союзников СССР по Антигитлеровской коалиции [4]. О проблемах развития русской и крымско-татарской культуры в период оккупации и о том, как это преподносилось в печатной пропаганде, идет речь в монографиях С.Б. Филимонова и И.А. Заатова [7; 20]. Наконец, в публикациях украинского историка М.И. Тяглого рассмотрен процесс создания и функционирования ан- тисемитской доктрины на страницах крымской периодики [18; 19].

Таким образом, место и роль проблемы военного коллаборационизма в нацистской пропагандистской модели, реализованной в Крыму при помощи прессы, ни целиком, ни частично еще не становились объектом научного исследования. Целью данной публикации является восполнить этот пробел, проанализировав следующие аспекты указанной проблемы: а) какие факты коллаборационистских проявлений были донесены до читателя; б) какие особенности подачи коллаборационистской тематики можно выявить в крымской прессе; и, наконец; в) какой была эффективность подобного рода публикаций для дальнейшего «воспроизводства» военного коллаборационизма.

Методологической основой исследования послужили принципы историзма и объективности. В ходе работы над статьей применялись основные общенаучные и конкретноисторические методы. Так, с помощью системного подхода были выделены основные особенности нацистского пропагандистского аппарата на территории Крыма и определено то место, которое занимала в нем пресса. Общая история развития крымской прессы в оккупационный период была восстановлена благодаря использованию историко-описательного метода. Наличие особенностей в подаче коллаборационистской тематики печатной пропагандой, появление или исчезновение тех или иных сюжетов, их трансформация проанали- 
зированы посредством историко-генетического метода. Наконец, выводы о количественных показателях материалов о военном коллаборационизме в оккупационной прессе вообще, их количестве и качестве в разные годы оккупации, об эффективности воздействия на конкретные целевые группы были сделаны на основе историко-сравнительного метода.

Анализ. На первом этапе оккупации Крыма психологической обработкой населения занимались соответствующие структуры 11-й немецкой армии. После окончания боевых действий, в сентябре 1942 г., на территории полуострова был создан специальный Штаб пропаганды «Крым», главной целью которого являлась нейтрализация последствий идеологической деятельности советской власти. Этот штаб имел разветвленную сеть представительств, посредством которой нацистские пропагандисты и их помощники из числа местного населения руководили крымскими учебными заведениями, театрами, библиотеками, музеями и т. д. Серьезную роль в формировании общественных настроений на оккупированных территориях играла пресса. В связи с этим при поддержке оккупантов выпускалось большое количество газет и прочей печатной продукции на русском, крымско-татарском и немецком языках (16 наименований за период оккупации) [17, с. 11-16].

Наиболее значительным периодическим изданием был «Голос Крыма» - орган Симферопольского городского управления. Первый номер этой газеты вышел 12 декабря 1941 г., а последний - 9 апреля 1944 года. В середине 1943 г. ее тираж составлял 80 тыс. экземпляров. В 1941 - начале 1942 г. газета выходила два раза в неделю на двух страницах, а в 1942-1944 гг. - три раза на четырех страницах. Розничная цена составляла 1 рубль, или 10 оккупационных пфеннигов. В 1943 г. (21 июля и 3 октября) газета выходила под названием «Голос Таврии». В этом же году появились и специализированные приложения к ней: «Женский листок» (с 21 мая 1943 г.) и «Молодость» (с 18 июля 1943 г.). Для других местных газет «Голос Крыма» являлся образцом и фактически источником публикаций. Кроме того, ни одно из остальных 12 русскоязычных изданий не существовало на протяжении всего периода оккупации [14, л. 25-26].
Главными редакторами газеты последовательно становились: В.В. Попов (12 декабря 1941 г. - 26 марта 1942 г.), А.И. Булдеев (26 марта 1942 г. - октябрь 1943 г.) и К.А. Быкович (октябрь 1943 г. - 9 апреля 1944 г.) [16, с. 107].

После своего окончательного оформления в виде четырехстраничного издания «Голос Крыма» в целом печатал материалы следующей направленности. Его первая и вторая страницы состояли из двух типов статей: порочащих советский строй, советских государственных, военных и научных деятелей и восхваляющих немецкий «новый порядок», успехи германской армии. Кроме того, на этих страницах помещались сводки с театров военных действий, международные новости (обычно переводы из немецких газет или перепечатки из более крупных оккупационных изданий), высказывания Гитлера и других видных нацистов, а также их биографии. Третья страница содержала материалы о жизни в городах и селах Крыма после их «освобождения от власти советов», о хозяйственной и культурной жизни полуострова при «новом порядке». При этом значительное место уделялось материалам, связанным с религиозной тематикой. Приказы, постановления, извещения Симферопольского городского управления и городского коменданта печатались на четвертой странице газеты. В основном они касались правил соблюдения комендантского часа, хозяйственной жизни города, переименования улиц и упорядочения торговли. Кроме того, на этой странице публиковались приказы о расстрелах жителей Симферополя с указанием их фамилий и совершенных преступлений.

«Голос Крыма» значительно выделялся на фоне других оккупационных газет написанными хорошим языком статьями о русской культуре и истории, а также достаточно высоким уровнем художественного оформления материалов. Однако в целом «аналитические» материалы в нем не отличались разнообразием. Из номера в номер в газете публиковались очень близкие по смыслу и тематике статьи, в которых восхвалялась нацистская Германия, критиковался коммунизм и порочился советский строй. Немало внимания отводилось и разоблачению так называемого «еврейского заговора»: почти каж- 
дый номер включал статьи антисемитского содержания ${ }^{1}$.

Выходившие в Крыму периодические издания находились под полным контролем оккупационных властей, которые влияли на них через отдел прессы Штаба пропаганды «Крым». В целях унификации весь материал, публиковавшийся в прессе на оккупированных территориях, утверждался сверху. Для этого в помощь редакциям, издававшим газеты на языках народов СССР, в Берлине, в Министерстве пропаганды выходил сборник, который назывался «Материалы для русских газет» ("Material für russische Zeitungen") ${ }^{2}$.

Одними из таких унифицированных материалов были публикации на тему участия иностранных граждан в военных усилиях Германии, которые стали появляться в «Голосе Крыма» практически сразу. Тем не менее до весны 1943 г. их было относительно немного - всего 10. По содержанию эти публикации можно условно разделить на три группы. В первой из них шла речь о «крестовом походе европейских народов против большевизма». По какимто причинам, известным только немецким кураторам, «Голос Крыма» четырежды публиковал подобные материалы: по одному разу о европейских добровольцах вообще, об испанской «Голубой дивизии», два - о французах на Восточном фронте. В них было минимум информативности и максимум пропаганды [3, 1941, № 4, 21 декабря; 1942, № 5, 15 января; 1942, № 8, 25 января; 1942, № 18, 1 марта].

Следующую группу представляют материалы о военных коллаборационистах представителях народов Крыма. В данном случае это две публикации о крымских татарах. Первая - перепечатка из немецкой газеты, которая озаглавлена «Татарские вспомогательные войска. С немецкими солдатами против общего врага». По стилю и содержанию эта публикация примыкает к предыдущей группе, то есть представляет собой исключительно продукт пропаганды. Вторая - «Парад в Курмане» - уже дает некоторое представление о месте полиции в системе оккупационного режима $[3,1942$, № 42, 24 мая; 1942, № 104, 18 октября].

Наконец, к третьей группе можно отнести материалы общего характера. В двух октябрьских номерах за 1942 г. были опублико- ваны две заметки о так называемом знаке отличия «За храбрость и заслуги для восточных народов», учрежденном указом Гитлера от 14 июля 1942 года. Этим знаком награждались гражданские и военные коллаборационисты из числа советских граждан. В публикациях «Голоса Крыма» без излишних подробностей говорится о том, что это за знак, кто мог его получить и как его следовало носить на гражданской одежде и военной форме [3, 1942, № 100, 9 октября; 1942, № 107, 25 октября].

В целом нельзя сказать, что до определенного момента газета «Голос Крыма» часто и подробно обращалась к тематике военного коллаборационизма. Публикации, речь о которых шла выше, можно охарактеризовать как появлявшиеся случайно и, наряду с другими материалами, просто отражавшие ту или иную сторону военной или оккупационной повседневности. Однако с весны 1943 г. ситуация изменилась так, что можно говорить об уникальности «Голоса Крыма» и его отличии от многих других изданий, выходивших на оккупированных территориях. Это связано с тем, что, начиная со второй половины 1942 г., в нацистской «восточной политике» и пропаганде важную роль стали играть Власовское движение и Русская освободительная армия (POA). Не остался в стороне от этих процессов и Крымский полуостров, где газета «Голос Крыма», обращаясь к теме РОА, оказалась фактически выразителем настроения некоторых слоев местного населения.

Власовская листовка - «Смоленский манифест» (начало 1943 г.) - получила сравнительную известность только в средней полосе России и осталась практически неизвестной на юге, тем более в Крыму. О бывшем советском генерале А.А. Власове на территории полуострова заговорили в связи со следующим по времени пропагандистским шагом немцев - появлением открытого письма А.А. Власова «Почему я встал на путь борьбы с большевизмом?». Именно этому документу, в котором он рассказывал «о своей жизни и своем опыте в СССР», объяснял причины, «побудившие его начать войну против сталинского режима», Власов был обязан своей популярностью среди некоторых слоев населения. В Крыму письмо появилось в марте 1943 г. в «Голосе Крыма» [3, 1943, № 33, 18 марта]. 
На него первым публично отреагировал бывший полковник советских ВВС, впоследствии бургомистр Ялты В.И. Мальцев, ставший одной из ключевых фигур в истории Власовского движения и РОА. В марте 1943 г. В.И. Мальцев прочитал «Открытое письмо» генерала А.А. Власова, которое произвело на него огромное впечатление. Ему показалось, что немцы, наконец, поменяли свою «восточную политику» и дают антисоветским силам возможность создать свой политический центр и собственные вооруженные силы для борьбы с коммунистами. Как и многие другие в то время, В.И. Мальцев ошибался, не зная, что немцы использовали имя бывшего советского генерала исключительно в пропагандистских целях. Тем не менее он начал действовать $[15$, с. 13$]$.

4 июня «Голос Крыма» опубликовал ответ В.И. Мальцева на письмо А.А. Власова. Он был написан в той же форме открытого письма и озаглавлен «Борьба с большевизмом - наш долг». В письме В.И. Мальцев рассказывал, как он прошел путь от «коммунизма к борьбе с ним» и призывал всех коммунистов последовать его примеру, отдав все силы на благо русского народа, то есть поддержать А.А. Власова и РОА [3, 1943, № 66, 4 июня].

18 июня 1943 г. при активном содействии В.И. Мальцева появился первый вербовочный пункт PОА на полуострове - в Евпатории, а уже 30 июня в Симферополе состоялся торжественный молебен по случаю открытия центрального вербовочного пункта. Как было отмечено в «Голосе Крыма», он «был открыт для проведения систематической разъяснительной работы, консультации, записи добровольцев и оформления их в ряды POA, так как сотни лучших людей нашей Родины уже подали заявления о вступлении в нее» [3, 1943, № 72, 18 июня; 1943, № 76, 27 июня; 1943, № 77, 30 июня].

Впоследствии В.И. Мальцев покинул Крым, чтобы вступить «добровольцем в POA». Этому событию, а также тем проводам, которые устроили генерал-майору в Ялтинском городском управлении, «Голос Крыма» посвятил отдельную заметку [3, 1943, № 71, 16 июня] ${ }^{3}$.

Следует сказать, что на этом публикации о Власовском движении в «Голосе Кры- ма» не закончились. После появления в Евпатории вербовочного пункта, на третьей странице газеты появилась рубрика «Уголок добровольца». В рамках и вне этой рубрики размещалась информация, посвященная формированию частей РОА, записи в нее добровольцев, их участию в боевых действиях, встречам с местным населением. Размещение материалов было довольно интенсивным, в результате чего за март - декабрь 1943 г. «Голос Крыма» опубликовал 43 статьи и заметки по власовской тематике [3, 1943, март декабрь]. В дальнейшем сотрудничество газеты и местной POА приняло такие тесные формы, что ее главный редактор К.А. Быкович стал поручиком этой армии [9, с. 161]. «Голос Крыма» не только способствовал включению крымской РОА в информационную повестку оккупированного полуострова. Посредством этой газеты все местные власовцы были прочно привязаны к Штабу пропаганды «Крым». Начальник штаба обер-лейтенант Фрей настоятельно рекомендовал своим подчиненным привлекать офицеров РОА «для непосредственного разъяснения обстановки и использования в качестве докладчиков на радио и в печати» $[14$, л. 24$]$. В связи с этим офицеры-пропагандисты капитаны Л. Станиславский, Г. Барятинский и А. Таманский активно выступали во второй половине 1943 г. со статьями в «Голосе Крыма», фактически являясь постоянными авторами газеты [3, 1943, июль - август].

Все вышеперечисленные мотивы появления публикаций о РОА в «Голосе Крыма» были в целом характерны и для прессы других оккупированных советских территорий. Однако на полуострове имелись свои причины, сязанные, прежде всего, с национальной политикой оккупантов. Создание крымской РОА подняло «русский вопрос» на качественно иной уровень в этой политике и привело к значительным изменениям в сфере межнациональных отношений на полуострове. Как известно, до 1943 г. нацисты активно пытались сделать крымских татар опорой своего оккупационного режима при явной дискриминации русских. Началось все с экономических привилегий по национальному признаку. Далее было создание мусульманских комитетов и помощь в религиозно-культурном возрожде- 
нии. И, наконец, в январе - феврале 1942 г. крымские татары получили возможность иметь свои коллаборационистские формирования. Подобного, за редкими исключениями, у русского населения не было [22, bl. 31-32].

Благосклонное отношение немцев к власовскому движению показало, что с дискриминацией русских (в определенной степени) покончено, а немецкая национальная политика в Крыму выходит на новые позиции. Одной из них должно было стать сотрудничество между коллаборационистами из различных этнических групп. В связи с этим следует отметить, что в крымских частях POА служили не только русские, но и крымские татары. Это подтверждает целый ряд публикаций в «Голосе Крыма», свидетельствовавших о «совместной борьбе татар и русских против большевизма»: «Плечом к плечу с РОА», «Борьба татар против большевизма», «Голос крови зовет меня» и тому подобные. Их основной смысл можно выразить следующей фразой: «Победа или смерть! Плечом к плечу с Русской Армией мы пойдем на борьбу за наше освобождение» [3, 1943, № 75, 25 июня; 1943, № 84, 16 июля; 1943, № 90, 30 июля].

Крымско-татарская пресса получила такие же указания. Поэтому, в ней можно было прочесть, например, такие высказывания. Так, 28 апреля 1943 г. орган Симферопольского мусульманского комитета - газета «Азат Кърым» - опубликовал передовую статью со следующим пассажем: «Русские интиллегенты, военные офицеры и крестьяне своим объединением вокруг генерала Власова показали, что они вышли на правильную дорогу. Отныне на фронтах татары, украинцы и донско-кубанские казаки неодиноки: в их ряды включаются и русские добровольцы. Отныне наступление, начатое из областей, освобожденных благодаря германским войскам, будет всеобщим наступлением наций, которые являются братьями по оружию» [10].

Стоит сказать, что изменения в подаче крымско-татарской тематики на страницах «Голоса Крыма» являются характерными и для других публикаций о невласовском военном коллаборационизме. После появления материалов о РОА она, по сути, осталась такой же бедной. Однако теперь в подобных публикациях имелась определенная система: практи- чески все они были встроены во власовскую тематику, даже если речь шла о европейских добровольцах, латышах, эстонцах или кубанских казаках [см., напр.: 3, 1943, № 35, 22 марта; 1943, № 39, 31 марта; 1943, № 51, 1 мая].

Оценивая пропагандистское воздействие «Голоса Крыма» на крымское население, следует иметь в виду несколько моментов. Если отталкиваться от воспоминаний свидетелей оккупации, то может сложиться впечатление, что в целом доверием у широких масс газета не пользовалась. Почти все авторы этих воспоминаний называют ее «воплями Геббельса», а журналистов - «нищими духом», за которых «стыдно, что они призывают радоваться нашим поражениям» [2, л. $53 ; 5$, л. $121 ; 6$, л. 96 об.].

Однако нужно учесть, что большинство этих воспоминаний писалось после 1945 года. В период же оккупации «Голос Крыма» существовал не сам по себе, а являлся одним из главных печатных органов в системе нацистской пропаганды на полуострове. И до середины 1943 г. эта система работала довольно эффективно. Газета вместе с другими подобными изданиями вполне справлялась с формированием у крымчан картины, выгодной оккупантам. А участие местных коллаборационистов в войне на стороне Германии вполне вписывалось в эту картину - их количество на полуострове в 1941-1943 гг. только росло. Тематика материалов «Голоса Крыма» и форма их подачи признавались настолько удачными, что газету использовали для идеологического воспитания личного состава в уже сформированных коллаборационистских формированиях, а не только для привлечения потенциальных добровольцев. Так, бывший советский военнопленный Л.В. Полуев, служивший в созданном немецкой морской разведкой Легионе «Черное море», вспоминал, что на политических занятиях им читали статьи из «Голоса Крыма», где «восхвалялись успехи немецкой армии и ее превосходство над другими» $[8$, с. 74$]$.

Эффект от этой печатной пропаганды хорошо виден даже в воспоминаниях крымских партизан. Так, один из руководителей партизанским движением на полуострове Н.Д. Луговой - вспоминал, что в 1942 г. зап- 
рещал в своем отряде использовать «Голос Крыма» для самокруток или даже в качестве... туалетной бумаги. Хотя на следующей странице он уже пишет, что выдержки из этой газеты, особенно с четвертой страницы, где печатались приказы о расстрелах симферопольцев, использовались комиссарами, политруками и агитаторами, чтобы подчеркнуть ужасы оккупационного режима $[12$, c. 187,189$]$.

Вообще же появление на территории Крыма POA серьезно обеспокоило советское военно-политическое руководство. И на это были свои причины. В военном отношении эти части не представляли сколько-нибудь значительной силы. По самым оптимистическим подсчетам, к весне 1944 г. в их рядах находилось не более 4 тыс. человек [16, с. 254]. Однако, как было показано выше, политико-пропагандистский вес РОА на полуострове оказался больше военного. Понимая значимость этой проблемы, советское руководство разработало целый комплекс соответствующих мероприятий. А их выполнение было возложено на крымских партизан и подпольщиков. Об одном из таких мероприятий, относящемся к лету 1943 г., в своих воспоминаниях поделился уже упоминавшийся Н.Д. Луговой. По его словам, партизаны следили за редактором «фашистской газеты "Голос Крыма" Быковичем», чтобы взорвать его маломагнитной миной. Правда, это покушение так и осталось неосуществленным [11, с. 315].

Таким образом, сотрудники «Голоса Крыма» вполне справлялись со своими обязанностями и до определенного момента удовлетворяли немецких кураторов. Тем не менее, начиная с осени 1943 г., газета стала вызывать у оккупационных властей серьезные нарекания. Как известно, этот год прошел под знаком ухудшения положения Вермахта на Восточном фронте. И это не могло не сказаться и на крымской ситуации. Скрыть поражения уже не представлялось возможным, поэтому все меньше людей верили немецкой пропаганде. Параллельно с этим с лета 1943 г. стало вновь набирать силу партизанское движение. Пользуясь поддержкой с «большой земли», крымские партизаны и подпольщики создали свой аппарат психологической войны, который уже почти не уступал немецкому, а в чем-то и переигрывал его. В связи с этим энтузиазм крымчан относительно мероприятий оккупационных властей заметно поубавился. И, в первую очередь, это коснулось процесса создания коллаборационистских формирований, поток добровольцев в которые закономерно иссяк. Более того, начался обратный процесс переходы на советскую сторону [16, с. 247-250, 254, 294-295, 340-343].

Также следует сказать, что во второй половине 1943 г. произошли события, повлиявшие на динамику развития Власовского движения в целом. А именно: после того как в ходе поездок на оккупированные территории генерал А.А. Власов позволил себе ряд высказываний, идущих вразрез с нацистской «восточной политикой», его фактически поместили под домашний арест и запретили выступать публично [21, с. 123-132].

Одним из последствий этих событий стало то, что власовская тематика начала исчезать со страниц коллаборационистской прессы. И на примере публикаций «Голоса Крыма» это видно особенно отчетливо. Так, если почти всю весну и лето 1943 г. материалы о POA печатались здесь почти в каждом номере, то ближе к осени этого года их количество заметно уменьшилось, а «Уголок добровольца» с 13 августа исчез вообще. В этот день вышел его последний - десятый - выпуск [3, 1943, № 96, 13 августа].

Отголоски проблем генерала Власова с нацистским руководством нашли своеобразное отражение на страницах «Голоса Крыма». Так, в январе 1944 г. Штаб пропаганды «Крым» в одном из своих отчетов констатировал, что среди населения имеется много сторонников так называемой «третьей силы». «Это - люди, - говорилось в отчете, - ожидающие окончательного завершения войны, которое наступит после полного поражения Германии и Советского Союза. Совершенно определенно, эти идеи косвенно или прямо направлены против немецких интересов. Несмотря на это, «Голос Крыма» опубликовал уже несколько статей, посвященных данному вопросу и созвучных общему мнению населения. Последней среди них является публикация «Третья мировая война» в номере от 7 января 1944 г., где речь идет о том, что Ан- 
глия и Америка третью мировую войну будут вести против СССР» [13, л. 34]. Сотрудников штаба беспокоило, что такие убеждения снизят «страх перед возвращением большевиков» и подорвут лояльность населения к оккупационным властям [14, л. 25].

Итогом подобных опасений стало то, что крымское власовское движение прекратило свое существование еще фактически до полного освобождения полуострова. А в феврале 1944 г. была поставлена финальная точка: немцы закрыли симферопольский вербовочный пункт POA [1, bl. 58].

Тем не менее использование темы РОА в целях пропаганды продолжалось и в 1944 г. За оставшиеся три месяца оккупации (с января по начало апреля) «Голос Крыма» опубликовал восемь материалов, где так или иначе упоминалась эта армия. Последним из них было стихотворение некоего Н. Саранчи, озаглавленное «Воинам РОА». Газета опубликовала его за неделю до начала советского наступления [3, 1944, № 41, 2 апреля].

Следует отметить, что вместе с темой POA со страниц «Голоса Крыма» за 1944 г. практически исчезают материалы и о других проявлениях военного коллаборационизма. А те, что публиковались, напоминали материалы 1941-1942 гг., в которых шла речь о «крестовом походе против большевизма» и «дружеском соратничестве добровольцев Востока с Германской армией» [3, 1944, № 35, 19 марта].

Результаты. Таким образом, можно констатировать, что проблема военного коллаборационизма на страницах оккупационной газеты «Голос Крыма» играла существенную роль, но только с определенного периода (с весны 1943 года). До этого ее место в той пропагандистской модели, которую нацисты реализовали в Крыму, было незначительным, а освещение - бессистемным. Эта ситуация изменилась коренным образом после появления на страницах «Голоса Крыма» публикаций на тему власовского движения и РОА. Во многом это было связано как с «раскручиванием» нацистами этого движения вообще, так и с сугубо крымскими аспектами - корректировкой национальной политики на полуострове. По этой причине с марта по сентябрь 1943 г. «Голос Крыма» фактически становится газетой власовского движения - случай для региональной прессы уникальный. А его публикации на коллаборационистскую тематику - весьма эффективное средство для психологической обработки крымчан и «воспроизводства» военного коллаборационизма. Тем не менее, начиная с поздней осени 1943 г., энтузиазм местного населения относительно РОА стал слабеть. Произошло это по целому ряду причин: коренной перелом на Восточном фронте, деятельность крымских партизан и подпольщиков и тому подобное. Наконец, существенную роль сыграла боязнь нацистов, что «Голос Крыма» и местная РОА станут площадкой для развития идей так называемой «третьей силы». Все это привело к тому, что к началу 1944 г. проблема военного коллаборационизма на страницах «Голоса Крыма» вновь, как и в первый год оккупации, стала освещаться мало и бессистемно. Однако в данном случае это уже не имело никакого значения. Нацистская пропагандистская модель на полуострове фактически была уничтожена - ее заявлениям в целом и таким отдельным структурам, как «Голосу Крыма», уже не верили.

\section{ПРИМЕЧАНИЯ}

1 Анализ тематики материалов газеты «Голос Крыма» за 1941-1944 гг. проведен автором статьи. Полный комплект газеты за эти годы хранится в архиве автора (Симферополь, Республика Крым).

${ }^{2}$ В Государственном архиве Республики Крым (Симферополь, Республика Крым) хранится комплект «Material für russische Zeitungen» за 1943-1944 годы.

${ }^{3}$ Как бывший летчик, В. И. Мальцев вступил в Русскую авиационную группу (Восточная Пруссии). Осенью 1944 г. на основе этой группы стали создаваться ВВС власовского Комитета освобождения народов России, командующим которыми в чине генерал-майора стал Мальцев.

\section{СПИСОК ЛИТЕРАТУРЫ}

1. Борьба казачества против советской власти в период Второй мировой войны (рукопись неизвестного автора) // Bundesarchiv-Militärarchiv (BArch). - MSg 149. Sammlung Vladimir Pozdnakoff (Vlasov-Bewegung). - MSg 149/7. - B1. 51-60.

2. Воспоминания Елены Григорьевны М., жительницы с. Ленинское (лето 1943 г.) // ГАРК. Ф. П-156. - ОП. 1. - Д. 39. - Л. 53-54. 
3. Голос Крыма. - 1941-1944.

4. Гуркович, В. Н. Образ врага (профашистские газеты «Голос Крыма» и «Азат Кърым» о союзниках СССР в годы Второй мировой войны) / В. Н. Гуркович // Историческое наследие Крыма. 2004. - № 8. - С. 140-147.

5. Дневник Ольги Михиной, жительницы г. Керчь (10 мая 1942 - 9 января 1943 г.) // ГАРК. Ф. П-156. - ОП. 1. - Д. 31. - Л. 121-161.

6. Дневник Хрисанфа Гавриловича Лашкевича, жителя г. Симферополя (22 июня 1941 - 7 ноября 1943 г.) // ГАРК. - Ф. П-156. -Оп. 1.-Д. 31.-Л. 56-103.

7. Заатов, И. А. Крымскотатарское сценическое искусство в материалах архивов и оккупационной прессы 1941-1944 гг. / И. А. Заатов. - Симферополь : Доля, 2015. - 348 с.

8. Кашин, В. В. Исповедь легионера / В. В. Кашин. - Нижний Тагил : Репринт, 2012. - 200 с.

9. Кохан, А. А. «Моя идеология была чужда идеологии советского человека»: к вопросу о составе и деятельности редакционных коллегий газеты «Голос Крыма» в 1941-1944 гг. / А. А. Кохан // Вестник РГГУ. Серия: История. Филология. Культурология. Востоковедение. - 2016. - № 10 (19). C. 154-164.

10. Куртиев, М. Передовая статья / М. Куртиев // Азат Кърым. - 1943. - № 34 (130).

11. Луговой, Н. Д. Побратимы / Н. Д. Луговой. Киев : Политиздат Украины, 1985. - 541 с.

12. Луговой, Н. Д. Страда партизанская: 900 дней в тылу врага. Дневниковые записи / Н. Д. Луговой. Симферополь : Эльиньо, 2004. - 732 с.

13. Об откликах населения на немецкую пропаганду (январь 1944 г.) // ГАРК. - Ф. П-156. - ОП. 1. Д. 26. - Л. 32-37.

14. Отчет о работе Штаба пропаганды «Крым» за июнь 1943 г. // ГАРК. - Ф. П-156. - Оп. 1. - Д. 26. Л. $24-28$.

15. Плющов, Б. Генерал Мальцев. История военно-воздушных сил Русского Освободительного Движения в годы Второй мировой войны (1942-1945) / Б. Плющов. - Сан-Франциско : Глобус, 1982.-113 с.

16. Романько, О. В. Крым в период немецкой оккупации. Национальные отношения, коллаборационизм и партизанское движение. 1941-1944 / О. В. Романько. - М. : Центрполиграф, 2014. $414 \mathrm{c}$.

17. Романько, О. В. Нацистская пропаганда в оккупированном Крыму (1942-1944): органы и формы деятельности / О. В. Романько // Ученые записки Петрозаводского государственного университета. Общественные и гуманитарные науки. - 2015. - № 5. - С. 11-16.

18. Тяглый, М. И. Антисемитская доктрина и ее место в пропагандистской модели, реализованной нацистами в оккупированном Крыму / М. И. Тяг- лый // Историческое наследие Крыма. - 2004. - № 5. C. 180-202.

19. Тяглый, М. И. Антисемитская доктрина на страницах крымско-татарской газеты «Азат Кърым» (1942-1944) / М. И. Тяглый // Наукові записки Інституту політичних і етнонаціональних досліджень ім. І. Ф. Кураса НАН України. - Київ, 2006. Вип. 31.- С. 132-151.

20. Филимонов, С. Б. Запретно-забытые страницы истории Крыма: поиски и находки историкаисточниковеда / С. Б. Филимонов. - Симферополь : Н. Оріанда, 2012. - 152 с.

21. Штеенберг, С. Генерал Власов / С. Штеенберг. - М. : Эксмо, 2005. - 320 с.

22. Einsatzgruppe, D. Des Chefs der Sicherheitspolizei (SD). Die Rekrutierung der Krimtataren. Stand: 15.Februar 1942 // BArch. - RH20. Armeeoberkommandos. -Bd. 5: AOK 11.-RH20-11/433. -B1. 13-32.

\section{REFERENCES}

1. Borba kazachestva protiv sovetskoy vlasti $\mathrm{v}$ period Vtoroy mirovoy voyny (rukopis neizvestnogo avtora) [The Struggle of the Cossacks against the Soviet Power during the Second World War (Manuscript by an Unknown Author)]. Bundesarchiv-Militärarchiv (BArch). MSg 149. Sammlung Vladimir Pozdnakoff (Vlasov-Bewegung). MSg 149/7. Bl. 51-60.

2. Vospominaniya Eleny Grigoryevny M., zhitelnitsy s. Leninskoe (leto 1943 g.) [Memories of Elena Grigoryevna M., Resident of the Leninskoe Village (Summer 1943)]. Gosudarstvennyy arkhiv Respubliki Krym [State Archive of the Republic of Crimea], F. P-156, Op. 1, D. 39, L. 53-54.

3. Golos Kryma, 1941-1944.

4. Gurkovich V.N. Obraz vraga (profashistskie gazety «Golos Kryma» i «Azat Kyrym» o soyuznikakh SSSR v gody Vtoroy mirovoy voyny) [The Image of the Enemy (Pro-Fascist Newspapers Voice of Crimea and Azat Kyrym about the Allies of the USSR during the Second World War)]. Istoricheskoe nasledie Kryma, 2004, no. 8, pp. 140-147.

5. Dnevnik Olgi Mikhinoy, zhitelnitsy g. Kerch (10 maya 1942 - 9 yanvarya 1943 g.) [The Diary of Olga Mikhina, Resident of Kerch (May 10, 1942 - January 9, 1943)]. Gosudarstvennyy arkhiv Respubliki Krym [State Archive of the Republic of Crimea], F. P-156, Op. 1, D. 31, L. 121-161.

6. Dnevnik Khrisanfa Gavrilovicha Lashkevicha, zhitelya g. Simferopolya (22 iyunya $1941-7$ noyabrya 1943 g.) [The Diary of Khrisanf Gavrilovich Lashkevich, Townsman of Simferopol (June 22, 1941 - November 7, 1943)]. Gosudarstvennyy arkhiv Respubliki Krym [State Archive of the Republic of Crimea], F. P-156, Op. 1, D. 31, L. 56-103. 
7. Zaatov I.A. Krymskotatarskoe stsenicheskoe iskusstvo $v$ materialakh arkhivov i okkupatsionnoy pressy 1941-1944 gg. [Crimean-Tatar Stage Art in the Materials of the Archives and Occupation Press of 1941-1944]. Simferopol, Dolya Publ., 2015.348 p.

8. Kashin V.V. Ispoved legionera [Confessions of a Legionnaire]. Nizhniy Tagil, Reprint Publ., 2012. 200 p.

9. Kokhan A.A. «Moya ideologiya byla chuzhda ideologii sovetskogo cheloveka»: k voprosu o sostave i deyatelnosti redaktsionnykh kollegiy gazety «Golos Kryma» v 1941-1944 gg. ["My Ideology Was Alien to the Ideology of the Soviet Man": on the Membership and Activities of the Editorial Boards of Newspaper Golos Kryma ('Voice of Crimea') in 19411944]. Vestnik RGGU. Seriya: Istoriya. Filologiya. Kulturologiya. Vostokovedenie, 2016, no. 10 (19), pp. 154-164.

10. Kurtiev M. Peredovaya statya [Editorial]. Azat Kyrym, 1943, no. 34 (130).

11. Lugovoy N.D. Pobratimy [Sworn Brothers]. Kiev, Politizdat Ukrainy Publ., 1985. 541 p.

12. Lugovoy N.D. Strada partizanskaya: 900 dney v tylu vraga. Dnevnikovye zapisi [Partisan Campaign: 900 Days Behind Enemy Lines. Diary Notes]. Simferopol, Elino Publ., 2004. 732 p.

13. Ob otklikakh naseleniya na nemetskuyu propagandu (yanvar 1944 g.) [About Responses of the Population to the German Propaganda (January 1944)]. Gosudarstvennyy arkhiv Respubliki Krym [State Archive of the Republic of Crimea], F. P-156, Op. 1, D. 26, L. 32-37.

14. Otchet o rabote Shtaba propagandy «Krym» za iyun $1943 \mathrm{~g}$. [Report about the Work of the Headquarters of the Propaganda 'Crimea' in June 1943]. Gosudarstvennyy arkhiv Respubliki Krym [State Archive of the Republic of Crimea], F. P-156, Op. 1, D. 26, L. 24-28.

15. Plyushchov B. General Maltsev. Istoriya voenno-vozdushnykh sil Russkogo Osvoboditelnogo Dvizheniya $v$ gody Vtoroy mirovoy voyny (19421945) [General Maltsev. History of the Air Force of the Russian Liberation Movement during the Second World War (1942-1945)]. San-Francisco, Globus Publ., $1982.113 \mathrm{p}$.

16. Romanko O.V. Krym v period nemetskoy okkupatsii. Natsionalnye otnosheniya, kollaboratsionizm i partizanskoe dvizhenie. 1941-1944 [Crimea during the German Occupation. National Relations, Collaborationism and Partisan Movement. 1941-1944]. Moscow, TsentrpoligrafPubl., 2014. 414 p.

17. Romanko O.V. Natsistskaya propaganda $\mathrm{V}$ okkupirovannom Krymu (1942-1944): organy i formy deyatelnosti [Nazi Propaganda in the Occupied Crimea (1942-1944): Bodies and Forms of Activity]. Uchenye zapiski Petrozavodskogo gosudarstvennogo universiteta. Obshchestvennye i gumanitarnye nauki, 2015, no. 5, pp. 11-16.

18. Tyaglyy M.I. Antisemitskaya doktrina i ee mesto $\mathrm{v}$ propagandistskoy modeli, realizovannoy natsistami v okkupirovannom Krymu [Anti-Semitic Doctrine and Its Place in the Propaganda Model Implemented by the Nazis in the Occupied Crimea]. Istoricheskoe nasledie Kryma, 2004, no. 5, pp. 180-202.

19. Tyaglyy M.I. Antisemitskaya doktrina na stranitsakh krymsko-tatarskoy gazety «Azat Kyrym» (1942-1944) [Anti-Semitic Doctrine on the Pages of the Crimean Tatar Newspaper Azat Kyrym (1942-1944)]. Naukovi zapiski Institutu politichnikh $i$ etnonatsional'nikh doslidzhen im. I. F. Kurasa NAN Ukraïni. Kijiv, 2006, iss. 31, pp. 132-151.

20. Filimonov S.B. Zapretno-zabytye stranitsy istorii Kryma: poiski i nahodki istorika-istochnikoveda [Forbidden-Forgotten Pages of the History of the Crimea: Searches and Discoveries of the Historian]. Simferopol, N. Orianda Publ., 2012.152 p.

21. Shteenberg S. General Vlasov [General Vlasov]. Moscow, Eksmo Publ., 2005. 320 p.

22. Einsatzgruppe D. Des Chefs der Sicherheitspolizei (SD). Die Rekrutierung der Krimtataren. Stand: 15. Februar 1942. BArch, RH 20. Armeeoberkommandos, Bd. 5: AOK 11; RH 20-11/ 433, Bl. 13-32.

\section{Information about the Author}

Oleg V. Romanko, Doctor of Sciences (History), Professor, Crimean Federal University named after V.I. Vernadsky, Prosp. akademika Vernadskogo, 20, 295007 Simferopol, Russian Federation, romanko1976@mail.ru, https://orcid.org/0000-0001-9898-8560

\section{Информация об авторе}

Олег Валентинович Романько, доктор исторических наук, профессор, Крымский федеральный университет им. В.И. Вернадского, просп. академика Вернадского, 20, 295007 г. Симферополь, Российская Федерация, romanko1976@mail.ru, https://orcid.org/0000-0001-9898-8560 